\title{
The Protective Effects of Citrus aurantium Flower Extract against 6-Hydroxydopamine-Mediated Cell Damage in Human Neuroblastoma SH-SY5Y Cells
}

\author{
Los Efectos Protectores del Extracto de Flor de Citrus aurantium Contra el Daño Celular \\ Mediado por 6-Hidroxidopamina en Células Humanas de Neuroblastoma SH-SY5Y
}

Leila Elyasi'; Mehrdad Jahanshahi' ${ }^{1}$; Hamed Ghazvini² \& Emsehgol Nikmahzar ${ }^{3}$

ELYASI, L.; JAHANSHAHI, M.; GHAZVINI, H. \& NIKMAHZAR, E. The protective effects of Citrus aurantium flower extract against 6-hydroxydopamine-mediated cell damage in human neuroblastoma SH-SY5Y Cells. Int. J. Morphol., 36(2):435-440, 2018.

SUMMARY: Parkinson's disease (PD) is described as a neurological condition, resulting from continuous degeneration of dopaminergic neurons. Currently, most treatments for neurodegenerative diseases are palliative. In traditional Iranian medicine, Citrus aurantium flower extract is used to treat some neural diseases, such as sleep disorders and anxiety. The tendency towards the use of medicinal herbs for the treatment of diseases (eg, seizure) is growing. Accordingly, we evaluated the antioxidant effects of $C$. aurantium flowers and analyzed their protective effects against 6-hydroxydopamine (6-OHDA)-mediated oxidative stress. In this study, $150 \mathrm{mM}$ of 6-OHDA was used to induce cellular damage. Also, MTT assay was performed to analyze cellular viability. Fluorescence spectrophotometry was performed to measure the intracellular reactive oxygen species (ROS) and calcium levels. Based on the findings, 6-OHDA could reduce cell viability. We also analyzed the effects of $C$. aurantium against neurotoxicity. The intracellular levels of ROS and calcium greatly improved in cells exposed to 6-OHDA. SH-SY5Y cell incubation with C. aurantium (400 and $600 \mathrm{mg} / \mathrm{mL}) \mathrm{induced}$ protective effects and decreased the biochemical markers of cell apoptosis. According to the findings, $C$. aurantium showed protective effects against neurotoxicity, caused by 6-OHDA; these protective properties were accompanied by antiapoptotic features. According to the findings, it seems that hydromethanolic $C$. aurantium extract can be used to prevent seizures.

KEY WORDS: Citrus aurantium; Parkinson's disease; 6-Hydroxydopamine; Apoptosis; Antioxidant activity.

\section{INTRODUCTION}

Today, Parkinson's disease (PD) is among the most prevalent disorders. It is caused by neuron degeneration in the pars compacta and striatal terminals (Tolleson \& Fang, 2013). Despite the unknown etiology of this disease, the possible causes involve neuroinflammation, oxidative stress, mitochondrial irregularities, and formation of pathological inclusions (Gandhi \& Plun-Favreau, 2016). Accordingly, PF can be prevented via reactive oxygen species (ROS) regulation, apoptotic cascade changes, inhibition of neuroinflammatory processes, and prevention of protein accumulation (Kanninen \& White, 2017).

Overall, 6-hydroxydopamine (6-OHDA) is a very common neurotoxic compound, which can selectively degenerate dopaminergic neurons (Zhang et al., 2017).
Today, researchers are focusing on the importance of SHSY5Y cells, as they exhibit features similar to dopaminergic neurons in PD models. In general, SH-SY5Y cell line expresses dopamine beta-hydroxylase, tyrosine hydroxylase, and dopamine transporters (Lopes et al., 2017). Consequently, it is applied in in vitro models of PD; moreover, it helps examine the protective effects of different drugs.

Long-term continuous treatment with chemical drugs increases the risk of side-effects. According to herbal remedies, a safe drug with minimal side-effects is highly required (Cao et al., 2017). Citrus species are used as medical herbs and food seasoning. These species contain active compounds, such as coumarin, flavonoid, and hesperidin (Ahmadi \&

\footnotetext{
${ }^{1}$ Neurosciences Research Center, Department of Anatomy, Faculty of Medicine, Golestan University of Medical Sciences, Gorgan, Iran.

${ }^{2}$ Immunogenetic Research Center, Mazandaran University of Medical Sciences, Sari, Iran.

${ }^{3}$ Neurosciences Research Center, Faculty of Medicine, Golestan University of Medical Sciences, Gorgan, Iran.
} 
Shadboorestan, 2016). Among different species, Citrus aurantium is a widely used medicinal plant, endemic to Iran. In traditional medicine, this herb is used to treat and manage neurodegenerative conditions, including seizures, weakness, sleep disorders, pain, and migraine (Amravati \& Suryawanshi, 2011).

Previous studies have confirmed the antioxidant, anticancer, and anti-inflammatory properties of. Moreover, flavonoid phytochemical studies have indicated the antioxidant capacity of this plant and its effects on free-radical reduction of support neuronal metabolism in Alzheimer's disease(Alhakmani et al., 2013). With this background in mind, we examined the protective effects of against 6-OHDA-mediated oxidative stress and cell line.

\section{MATERIAL AND METHOD}

\section{Cell Culture and Treatment}

Substances. The following substances were provided by Sigma-Aldrich Co. (MI, USA): hesperidin, rhodamine 123, DADLE, fura-2-acetoxymethyl ester (fura-2-AM), MTT, 6OHDA, and 2',7'-dichlorodihydrofluorescein diacetate (DCFH-DA). Also, DMEM medium was procured from Sigma. Cell Signaling Technology (MA, USA) provided the primary antibodies, including polyclonal anti-caspase-3 antibodies.

Santa Cruz Biotechnology Co. (USA) provided the primary monoclonal anti-cytochrome-c antibodies. GE Healthcare (NJ, USA) supplied horseradish peroxidase (HRP)-conjugated secondary antibodies, and Biocera (East Sussex, UK) provided the culture reagents, penicillinstreptomycin solution, fetal bovine serum, and EDTA. Finally, SPL Life Sciences Co. (South Korea) supplied the cell culture flasks and dishes.

Extract preparation. C. aurantium was obtained from a local market. We used the fresh petals of the plant in this study. C. aurantium was dried, ground, and mixed with methanol (95\%) to a weight/volume ratio of 1:10 at room temperature for $48 \mathrm{~h}$. The collected extracts were filtered, condensed by a rotary evaporator, and kept at $18^{\circ} \mathrm{C}$ before use (Hashemi et al., 2016).

Cell culture. SH-SY5Y cell line was supplied by the National Cell Bank of Iran. DMEM (containing $100 \mathrm{mg} / \mathrm{mL}$ of streptomycin and $100 \mathrm{U} / \mathrm{mL}$ of penicillin), was used for cell growth; every 2 days, the medium was replaced. $\mathrm{ACO}_{2}$ incubator was used to maintain the cells at a temperature of
$37{ }^{\circ} \mathrm{C}$ (saturated humidity, $95 \%$ air and $5 \% \mathrm{CO}_{2}$ ). Before each experiment, dimethyl sulfoxide (DMSO) was used to dissolve 6-OHDA and C. aurantium.

In experiment I, various 6-OHDA concentrations (50, $100,150,200$, and $250 \mu \mathrm{M}$ ) were used to incubate the cells for 24 hours. MTT assay was performed to detect the IC50 of 6-OHDA. In experiment II, the cells were pretreated with varying $C$. aurantium concentrations $(100,200,400$, and $600 \mathrm{mg} / \mathrm{mL}$ ) for $24 \mathrm{~h}$ and incubated with 6-OHDA (effective dose) for $30 \mathrm{~min}$. A 96-well plate (5000 cell/well) was used to seed the cells for MTT and perform intracellular ROS and calcium assays. In addition, to grow the cells for Western blot analysis, a 6-well plate was used for $24 \mathrm{~h}$.

Cell viability. For the analysis of cell viability, MTT was reduced into formazan, dissolved in phosphate-buffered saline (PBS), and added to the culture. After incubation for 120 minutes at $37^{\circ} \mathrm{C}$, the medium was discarded and DMSO $(100 \mu \mathrm{m})$ was added to the wells. Spectrophotometry $(490$ $\mathrm{nm}$ ) was performed, using a microplate reader (DGR Instruments, Germany) to determine the optical density (Kaeidi et al., 2012).

ROS level measurements. The intracellular level of ROS was measured with 2', 7'-dichlorofluorescin-DA (DCF-DA), which reacts with ROS and produces DCF (a fluorescent dye). DCF, which is trapped inside the cell, can be examined to determine the level of ROS (Bass et al., 1983). Following treatment, cell incubation was performed with DCF-DA (20 $\mu \mathrm{m}$ in DMSO) during $30 \mathrm{~min}$ at a temperature of $37^{\circ} \mathrm{C}$. The cells were evaluated using a fluorometer (SLX808; emission, 528/20; excitation, 485/20) after removing the extra dye.

Western blotting. In order to detect caspase-3, we applied Western blotting. For this purpose, the cells were rinsed with PBS and treated with 1-methyl-4-phenyl-pyridinium (MPP, $500 \mathrm{mM}$ ) for 24 hours. In order to detect cytochrome c, lysing was performed on ice for $30 \mathrm{~min}$ in a buffer, consisting of HEPES (20 mM), $\mathrm{NaCl}(500 \mathrm{mM}), \mathrm{MgCl} 2(1.5 \mathrm{mM}), 20 \%$ glycerol, $0.1 \%$ triton X100, EDTA (0.2 mM), aprotinin (1.7 $\mathrm{mg} / \mathrm{mL})$, antipain $(1.5 \mathrm{mM})$, pepstatin $(1 \mathrm{mM})$, dithiothreitol (DTT, $1 \mathrm{mM}$ ), phenylmethylsulfonyl fluoride (PMSF, 0.5 $\mathrm{mM}$ ), and $0.5 \%$ sodium dodecyl sulfate (SDS). Subsequently, centrifugation of the lysates was carried out at $13,600 \mathrm{~g}$ during $30 \mathrm{~min}$ at a temperature of $4{ }^{\circ} \mathrm{C}$. After discarding the supernatants, the pellets were resuspended in buffer and sonicated for $10 \mathrm{~s}$

In order to detect more proteins, a buffer containing $\mathrm{NaCl}(150 \mathrm{mM}), 1 \% \mathrm{NP}-40,0.02 \%$ sodium azide, PMSF $(10 \mathrm{mg} / \mathrm{mL})$, and tris- $\mathrm{HCl}(50 \mathrm{mM})$ was used for cell lysis on ice during $30 \mathrm{~min}$; afterwards, they were centrifuged at 


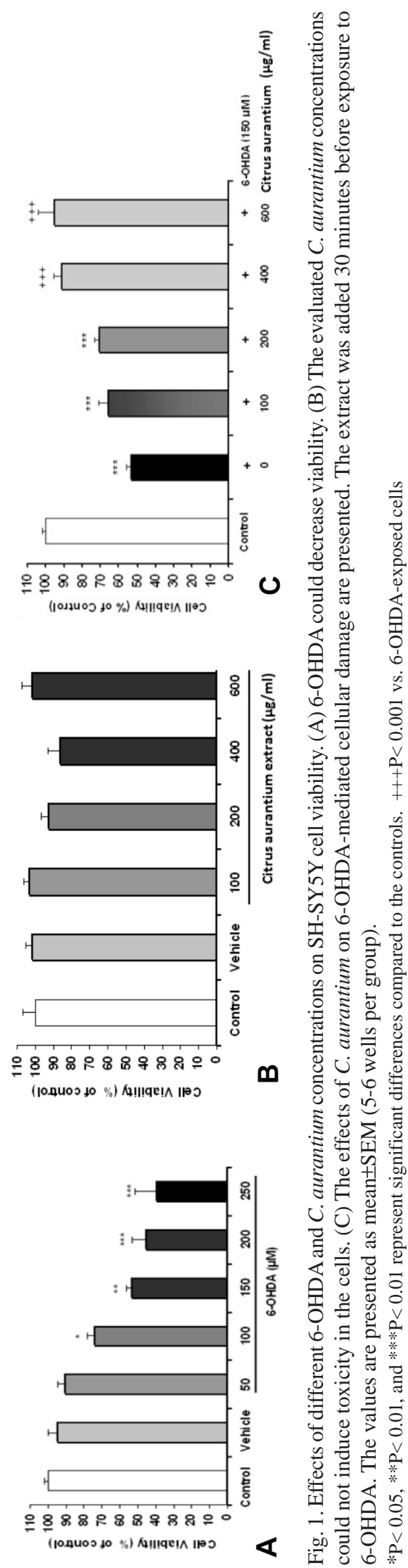

$12000 \mathrm{~g}$ for $2 \mathrm{~min}$ at a temperature of $4{ }^{\circ} \mathrm{C}$. To measure the level of proteins, Bradford assay was performed.

Protein samples of equal amounts were resuspended in buffer. Then, 10 $\%$ SDS-PAGE was performed, and the samples were transferred to a polyvinylidene difluoride membrane. Following blockage with tris-buffered saline, primary and HRP-conjugated secondary antibodies were used to incubate the membranes. Afterwards, visualization was carried out using an autoradiography film. For quantification, Quantity One ${ }^{\circledR}$ software package (BioRad) was applied. The collected values were normalized with respect to beta-actin reference bands (Elyasi et al., 2014).

Measurement of intracellular calcium level. The intracellular concentration of free calcium ions was measured in this study. The cells were grown to confluence and rinsed in suspensions. For incubation (at $25-37^{\circ} \mathrm{C}$ during 15-60 minutes), stock solution of Fura 2-AM (1 mM) was added to DMSO and loaded with Fura 2 acetoxymethyl ester $(3 \mathrm{mM})$; following that, the cells were rinsed with PBS twice. The intracellular level of calcium was determined at $37{ }^{\circ} \mathrm{C}$ with a fluorometer (excitation, 340/380 nm; emission, $510 \mathrm{~nm}$ ) (Kaeidi et al.).

Data analysis. The values are presented as mean \pm SEM. ANOVA and NewmanKeuls tests were used to determine the differences between the groups in terms of MTT, ROS, and calcium levels. Through band densitometry, beta-actin and caspase- 3 band densities were measured and presented as protein/beta-actin ratio. ANOVA and Newman-Keuls tests were performed to compare the average values between the groups (significance level, $\mathrm{P}<0.05$ ) (Kaeidi et al.).

\section{RESULTS}

Cell viability analysis. In order to assess the effects of 6-OHDA and the extracts $(100,200,400$, and $600 \mathrm{mg} / \mathrm{mL})$ on cell viability, MTT assay was carried out. According to Figure 1A, 6-OHDA could reduce cell viability in a dosedependent fashion. In groups receiving 100, 150, 200, and $250 \mathrm{~mm}$ of 6-OHDA, major toxicity was reported. Nevertheless, we used $150 \mathrm{lM}$ of 6-OHDA (relative cell viability, $55.5 \pm 1.38 \%$ ) to induce toxicity and examine the effects of the extracts.

Based on the findings, $24 \mathrm{~h}$ cell treatment with various doses of the extract $(100,200,400$, and $600 \mathrm{mg} / \mathrm{mL})$ exerted no major effects on the viability of the cells (Fig. 1B). Incubation of the extract at 400 and $600 \mathrm{mg} / \mathrm{mL}$ could majorly inhibit 6-OHDA-mediated toxicity; however, it did not inhibit cellular damage at doses of 100 and $200 \mathrm{mg} / \mathrm{mL}$ (Fig. 1C). Consequently, 400 and 600 $\mathrm{mg} / \mathrm{mL}$ concentrations were chosen for the subsequent experiments in the study.

Measurement of intracellular ROS level. Fluorescence spectrophotometry (DCFH-DA; excitation, $528 / 20 \mathrm{~nm}$; emission, $528 / 20 \mathrm{~nm}$ ) was performed to measure the intracellular ROS level in 6-OHDA $(150 \mu \mathrm{M})$-exposed cells. A noticeable increase in DCF signals was observed in the exposed cells, compared to the controls. On the other hand, ROS formation significantly decreased in cells exposed to the extract ( 400 and $600 \mathrm{mg} / \mathrm{mL}$ ), compared to the 6-OHDAtreated group (Fig. 2). 


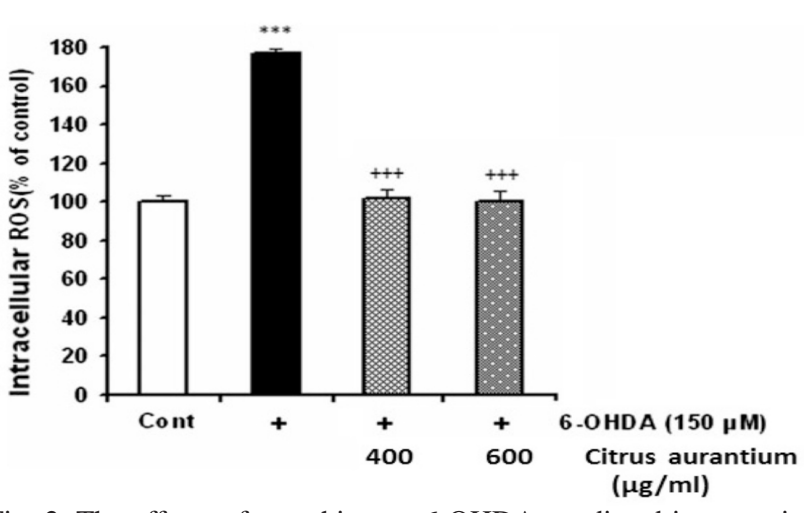

Fig. 2. The effects of morphine on 6-OHDA-mediated increase in intracellular ROS level. The 24-hour 6-OHDA exposure majorly improved the intracellular ROS level, while $C$. aurantium incubation (400 and $600 \mathrm{mg} / \mathrm{mL}$ ) entirely repressed it. The values are presented as mean \pm SEM (5-6 wells per group).

$* * * \mathrm{P}<0.001$ vs. controls; $+++\mathrm{P}<0.001$ vs. 6 -OHDA-exposed cells.

Western blotting of caspase-3 in the cells. Caspase- 3 activation was measured to identify the mediators of 6OHDA apoptosis. By using the 6-OHDA medium, control, and 6-OHDA medium $+C$. aurantium ( 400 and $600 \mathrm{mg} / \mathrm{mL}$ ), cell incubation was performed during $24 \mathrm{~h}$. The caspase-3 level increased in the 6-OHDA-exposed group, compared to the controls $(\mathrm{P}<0.001)$. Based on the findings, 400 and $600 \mathrm{mg} / \mathrm{mL}$ of $C$. aurantium (the most influential concentrations in previous analyses) could majorly diminish the upregulation of cleaved caspase-3, resulting from 6OHDA exposure (Fig. 3).

Measurement of $\mathrm{Ca} 2+$ level in the cells. Evaluation of cells loaded with Fura 2-AM indicated a significant increase in intracellular calcium (Ca2+) level in 6-OHDA-exposed cells. However, this increase was not recorded in groups receiving the extract (400 or $600 \mathrm{mg} / \mathrm{mL}$ ) plus 6-OHDA (Fig. 4).

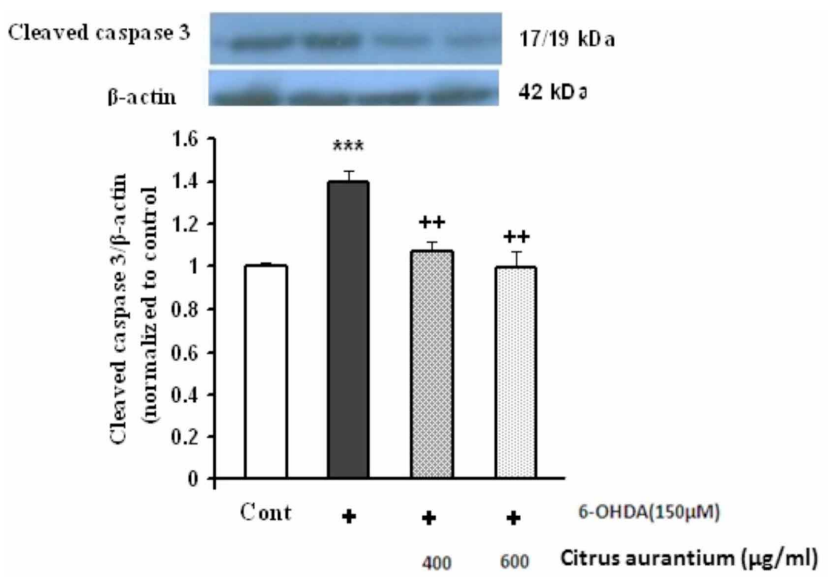

Fig. 3. Caspase-3 protein activation in 6-OHDA-exposed cells. The values in the graph represent \pm SEM band density in the groups. $* * * \mathrm{P}<0.05$ in comparison with the controls, $++\mathrm{P}<0.001$ in comparison with the 6-OHDA-exposed group.

\section{DISCUSSION}

PD is recognized as one of the most prevalent neurodegenerative diseases, associated with dopaminergic

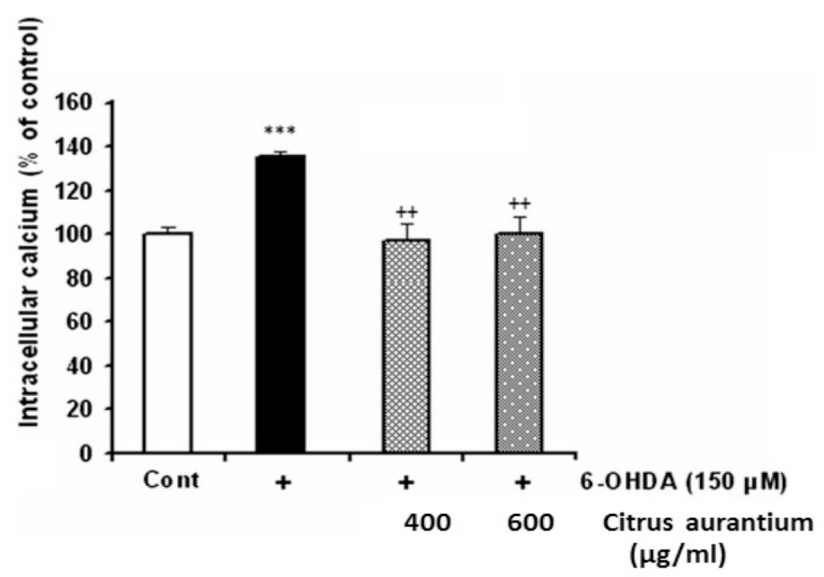

Fig. 4. The effects of $C$. aurantium extract on 6-OHDA-mediated increase in the intracellular level of calcium. The findings are expressed as mean \pm SEM ( 5 to 6 wells per group).

$* * * \mathrm{P}<0.001$ vs. controls, $++\mathrm{P}<0.01$ vs. 6 -OHDA-exposed cells

neuron damage in the pars compacta. However, etiology of this type of cell death is not clear yet (Thomas, 2009). Overall, Citrus species are considered as major supplies of bioactive compounds and antioxidants (Fernández-López et al., 2005; Jayaprakasha \& Patil, 2007). In the present study, in an in vitro model of PD, $C$. aurantium could majorly maintain cell viability and downregulate apoptotic signals, based on the analysis of ethanolic extracts; hence, C. aurantium could exhibit protective and neurorestorative characteristics. Nevertheless, this question remains as to how the extracts apply their protective effects at cellular or molecular level (Schwanz et al., 1996) .

Overall, oxidative stress has major contributions to the pathogenesis of PD and lipid, protein, and DNA damage; as a result, it can lead to the degeneration of dopaminergic neurons (Zhang et al., 2000). The present results indicated that $C$. aurantium could suppress the 6-OHDA-mediated production of ROS (Fig. 2). On the other hand, overproduction of ROS might cause major damages to mitochondrial membranes, release apoptosis-inducing factors, and activate the caspase cascade.

In the present research, the effect of $C$. aurantium on caspase-3 activity was evaluated via immunoblotting in 6OHDA-exposed cells. According to various studies, PDassociated neuronal death is majorly related to caspase-3 
activation. In the present study, cell damage, induced by 6OHDA, improved the caspase-3 activity. Moreover, cell incubation with $C$. aurantium decreased the level of elevated parameters (Fig. 3). Based on these findings, the efficacy of morphine against 6-OHDA-mediated toxicity could be reduced due to its antioxidant and antiapoptotic properties, exerted via ROS reduction and caspase-3 suppression. In fact, $C$. aurantium mechanism seems to involve mitochondrial apoptosis modulation, thereby revealing new aspects of its protective activities.

According to various studies, neurodegeneration and apoptosis resulting from neurotoxins are associated with increased calcium entry (Dryanovski et al., 2013). Changes in $\mathrm{Ca} 2+$ homeostasis, which lead to an increase in intracellular $\mathrm{Ca} 2+$ level, have been suggested in PD models. Based on the findings, $C$. aurantium can decrease the level of calcium. The neuroprotective effects might be, at least partly, associated with channel blockade induced by $C$. aurantium; nevertheless, this mechanism should be explained in future studies.

Considering the variety of factors affecting cell culture analyses, every model should be carefully selected and the results should be verified with respect to different models to reach definite conclusions. Since cell culture models are of limited clinical relevance, further in vivo studies can complement the in vitro findings.

Based on the findings, C. aurantium can protect $\mathrm{SH}-$ SY5Y cell line against cell death and neurodegeneration, resulting from 6-OHDA exposure. The antioxidant, calcium-blocking, and antiapoptotic properties of $C$. aurantium seem to be involved in its protective potential. Nevertheless, the characteristics of the protective pathway should be clarified in future studies.

ACKNOWLEDGMENTS. This study was supported by Neurosciences Research Center. The funding source was not involved in any stages of the study.

ELYASI, L.; JAHANSHAHI, M.; GHAZVINI, H. \& NIKMAHZAR, E. Los efectos protectores del extracto de flor de Citrus aurantium contra el daño celular mediado por 6hidroxidopamina en células humanas de neuroblastoma SH-SY5Y. Int. J. Morphol., 36(2):435-440, 2018.

RESUMEN: La enfermedad de Parkinson (EP) se describe como una afección neurológica que resulta de la degeneración continua de las neuronas dopaminérgicas. Actualmente, la mayoría de los tratamientos para las enfermedades neurodegenerativas son paliativos. En la medicina tradicional iraní, el extracto de flor de Citrus aurantium se usa para tratar algunas enfermedades neurológicas, como los trastornos del sueño y la ansiedad. La tendencia hacia el uso de las medicinas para el tratamiento de enfermedades (por ejemplo, convulsiones) está creciendo. Por consiguiente, el objetivo de este trabajo consistió en evaluar los efectos antioxidantes de las flores de C. aurantium y analizar sus efectos protectores contra el estrés oxidativo mediado por la 6hidroxidopamina (6-OHDA). En este estudio, se usó $150 \mathrm{mM}$ de 6-OHDA para inducir daño celular. Además, se realizó un ensayo de MTT para analizar la viabilidad celular. La espectrofotometría de fluorescencia se realizó para medir las especies reactivas de oxígeno (ROS) intracelulares y los niveles de calcio. En base a los hallazgos, 6-OHDA podría reducir la viabilidad celular. También analizamos los efectos de $C$. aurantium contra la neurotoxicidad. Los niveles intracelulares de ROS y calcio se expandieron a las células expuestas a 6-OHDA. La incubación de células SH-SY5Y con C. aurantium ( 400 y $600 \mathrm{mg} / \mathrm{ml}$ ) indujo efectos protectores y disminuyó los marcadores bioquímicos de la apoptosis celular. De acuerdo con los hallazgos, C. aurantium mostró efectos protectores contra la neurotoxicidad, causada por 6-OHDA; estas propiedades protectoras fueron acompañadas por características antiapoptóticas. Según los hallazgos, parece que el extracto hidrometanólico de C. aurantium se puede usar para prevenir las convulsiones.

PALABRAS CLAVE: Citrus aurantium; Enfermedad de Parkinson; 6-Hidroxidopamina; Apoptosis; Antioxidant activity.

\section{REFERENCES}

Ahmadi, A. \& Shadboorestan, A. Oxidative stress and cancer; the role of hesperidin, a citrus natural bioflavonoid, as a cancer chemoprotective agent. Nutr. Cancer, 68(1):29-39, 2016.

Alhakmani, F.; Kumar, S. \& Khan, S. A. Estimation of total phenolic content, in-vitro antioxidant and anti-inflammatory activity of flowers of Moringa oleifera. Asian Pac. J. Trop. Biomed., 3(8):623-7, 2013.

Amravati, J. \& Suryawanshi, S. An overview of Citrus aurantium used in treatment of various diseases. Afr. J. Plant Sci., 5:390-5, 2011.

Bass, D. A.; Parce, J. W.; Dechatelet, L. R.; Szejda, P.; Seeds, M. C. \& Thomas, M. Flow cytometric studies of oxidative product formation by neutrophils: a graded response to membrane stimulation. J. Immunol., 130(4):1910-7, 1983.

Cao, Q.; Qin, L.; Huang, F.; Wang, X.; Yang, L.; Shi, H.; Wu, H.; Zhang, B.; Chen, Z. \& Wu, X. Amentoflavone protects dopaminergic neurons in MPTP-induced Parkinson's disease model mice through PI3K/Akt and ERK signaling pathways. Toxicol. Appl. Pharmacol., 319:80-90, 2017.

Dryanovski, D. I.; Guzman, J. N.; Xie, Z.; Galteri, D. J.; Volpicelli-Daley, L. A.; Lee, V. M.; Miller, R. J.; Schumacker, P. T. \& Surmeier, D. J. Calcium entry and a-synuclein inclusions elevate dendritic mitochondrial oxidant stress in dopaminergic neurons. J. Neurosci., 33(24):10154-64, 2013.

Elyasi, L.; Eftekhar-Vaghefi, S. H. \& Esmaeili-Mahani, S. Morphine protects SH-SY5Y human neuroblastoma cells against 6-hydroxydopamineinduced cell damage: involvement of anti-oxidant, calcium blocking, and anti-apoptotic properties. Rejuvenation Res., 17(3):255-63, 2014.

Fernández-López, J.; Zhi, N.; Aleson-Carbonell, L.; Pérez-Alvarez, J. A. 
ELYASI, L.; JAHANSHAHI, M.; GHAZVINI, H. \& NIKMAHZAR, E. The protective effects of Citrus aurantium flower extract against 6-hydroxydopamine-mediated cell damage in human neuroblastoma SH-SY5Y Cells. Int. J. Morphol., 36(2):435-440, 2018.

\& Kuri, V. Antioxidant and antibacterial activities of natural extracts: application in beef meatballs. Meat Sci., 69(3):371-80, 2005.

Gandhi, S. \& Plun-Favreau, H. Mutations and mechanism: how PINK1 may contribute to risk of sporadic Parkinson's disease. Brain, 140(1):25,2016

Hashemi, S. M. B.; Amininezhad, R.; Shirzadinezhad, E.; Farahani, M. \& Yousefabad, S. H. A. The antimicrobial and antioxidant effects of Citrus aurantium L. flowers (Bahar Narang) extract in traditional yoghurt stew during refrigerated storage. J. Food Saf., 36(2):153-61, 2016.

Jayaprakasha, G. K. \& Patil, B. S. In vitro evaluation of the antioxidant activities in fruit extracts from citron and blood orange. Food Chem., 101(1):410-8, 2007.

Kaeidi, A.; Esmaeili-Mahani, S.; Abbasnejad, M.; Sheibani, V.; Rasoulian, B.; Hajializadeh, Z. \& Pasban-Aliabadi, H. Satureja khuzestanica attenuates apoptosis in hyperglycemic PC12 cells and spinal cord of diabetic rats. J. Nat. Med., 67(1):61-9, 2012.

Kanninen, K. M. \& White, A. R. Type-I interferons in Parkinson's disease: innate inflammatory response drives fate of neurons in model of degenerative brain disorder: An editorial comment on 'Type-I interferons mediate the neuroinflammatory response and neurotoxicity induced by rotenone. J. Neurochem., 141(1):9-11, 2017.

Lopes, F. M.; da Motta, L. L.; De Bastiani, M. A.; Pfaffenseller, B.; Aguiar, B. W.; de Souza, L. F.; Zanatta, G.; Vargas, D. M.; Schönhofen, P.; Londero, G. F.; de Medeiros, L. M.; Freire, V. N.; Dafre, A. L.; Castro, M. A.; Parsons, R. B. \& Klamt, F. RA differentiation enhances dopaminergic features, changes redox parameters, and increases dopamine transporter dependency in 6-hydroxydopamine-induced neurotoxicity in SH-SY5Y cells. Neurotox. Res., 31(4):545-59, 2017.

Schwanz, P.; Kimball, B. A.; Idso, S. B.; Hendrix, D. L. \& Polle, A. Antioxidants in sun and shade leaves of sour orange trees (Citrus aurantium) after long-term acclimation to elevated CO2. J. Exp. Bot., 47(12):1941-50, 1996.

Thomas, B. Parkinson's disease: from molecular pathways in disease to therapeutic approaches. Antioxid. Redox Signal., 11(9):2077-82, 2009.

Tolleson, C. M. \& Fang, J. Y. Advances in the mechanisms of Parkinson's disease. Discov. Med., 15(80):61-6, 2013

Zhang, J.; Cai, Q.; Jiang, M.; Liu, Y.; Gu, H.; Guo, J.; Sun, H.; Fang, J. \& Jin, L. Mesencephalic astrocyte-derived neurotrophic factor alleviated 6-OHDA-induced cell damage via ROS-AMPK/mTOR mediated autophagic inhibition. Exp. Gerontol., 89:45-56, 2017.

Zhang, Y.; Dawson, V. L. \& Dawson, T. M. Oxidative stress and genetics in the pathogenesis of Parkinson's disease. Neurobiol. Dis., 7(4):24050,2000 .
Corresponding Author:

Prof. Dr. Mehrdad Jahanshahi

Department of Anatomy, Neuroscience Research Center Faculty of medicine, Golestan University of medical Sciences km 4 Gorgan-Sari road (Shastcola) Gorgan

IRAN

E-mail: mejahanshahi@yahoo.com

Received: 04-07-2017

Accepted: 23-12-2017 